\title{
The 2007 French Presidential Election
}

\author{
BertRAND LEMENNICIER University of Paris II \\ Hororine LescieuX-Katir University of Paris II \\ BERNARD GROFMAN University of California, Irvine
}

\section{Introduction}

In his classic essay on democracy, Anthony Downs (1957) wrote that "the basic determinant of how a nation's political life develops is the distribution of voters along the political scale." Adapting the spatial approach of Harold Hotelling (1929), Downs's basic model posits single-peaked voter's preferences along a unidimensional left-right continuum. The best known part of Downs's work deals with two-party plurality-based competition. Here, the median voter plays a key role in determining the winner and in shaping the incentives for the structure of party competition by creating centripetal pressures for parties and candidates to modify their platforms to better match the views of the median voter. This unidimensional model can, however, be readily extended to the multiparty case, as

\begin{abstract}
Acknowledgments: This paper is an extension of an earlier conference paper (2007) by the first two authors, Bertrand Lemennicier and Honorine Lescieux-Katir: "Peut-on prédire le résultat des élections présidentielles d'avril 2007 à partir de la distribution des intentions de votes le long d'un axe politique gauche-droite?" The Institut de Recherches sur la Gouvernance et l'Économie des Institutions (IRGEI) paper was presented to a mini-symposium on forecasting the French presidential election held in May at the University of Paris II between the two rounds. Grofman's participation in this project is partially supported by the Jack W. Peltason (Bren Foundation) Endowed Chair at UCI and under a Social Sciences and Humanities Research Council of Canada (SSHRCC) grant to study political competition. We are indebted to Sue Ludeman for secretarial and bibliographic services.
\end{abstract}

Bertrand Lemennicier, Department of Economics and Institut de Recherches sur la Gouvernance et l'Économie des Institutions (IRGEI), University of Paris, II, PantheonAssas, 1 Rue d'Ulm, Paris, France, 75231, bertrand.lemennicier@gmail.com.

Honorine Lescieux-Katir, Department of Economics and Institut de Recherches sur la Gouvernance et l'Économie des Institutions (IRGEI), University of Paris, II, Pantheon-Assas, 1 Rue d'Ulm, Paris, France, 752

Bernard Grofman, Department of Political Science and Center for the Study of Democracy, University of California, Irvine, Irvine, CA. 92697, bgrofman@uci.edu. 
long as we recognize that, for a fixed distribution of voter preferences, the use of different electoral rules can create different incentives for voters and parties (Cox, 1997).

The goal of this paper is to apply the basic Downsian one-dimensional model to predict, ex ante, the outcome of the French presidential election of April-May 2007 by using past French presidential elections over the period 1965-2007. The French community of election forecasters of the 2007 presidential election, besides pollsters, is composed of a small group of economists, who use simple models of voter behaviour. Based on a reward-punishment behaviour of citizens, these models propose a conventional vote function with two or more independent macro variables, like log of unemployment rate and popularity of the incumbent president several months before the election, to predict outcomes (see review in Lemennicier, 2007). ${ }^{1}$ These models vary in methods and results, but they issue "true" forecasts, that is, they present predictions well in advance of the election. For example, they might hypothesize that median voter preferences are determined by reaction to unemployment rates, so that, when unemployment rises, the median voter votes against the incumbent party by "punishing" the incumbent government for its failure to adequately manage the economy (see, for example, Nordhaus, 1975).

Our analysis, which is based on a spatial median voter model, departs to a considerable extent from the models based on governmental rewardpunishment behaviour by citizens. We rely on the pre-election distribution of intended votes one month before the election, using data taken from TNS-SOFRES presidential election surveys since $1981 .^{2}$ Unlike the simple models of voter behaviour, which are based entirely on the demand side of political preferences of the (median) citizen, our spatial approach is rooted in the supply side of "political competition," in which the distribution of expected votes plays a key role as parties strategically compete to locate their political platforms closest to the overall median voter.

We proceed in the following manner. One month before the AprilMay 2007 presidential election - that is, in March 2007-we estimated the pre-election distribution of intended votes, using Theil's (1966) correction for systematic bias that has been observed in past presidential elections. The position of the median voter in this estimated distribution was found, and the distance to this position of the two leaders of the major left- and right-wing parties was calculated. After verifying that the median voter model worked well in previous presidential elections, that is, that the winner usually was the candidate closest to the position of the overall median voter, we hypothesize that the winner in 2007 will be one of the two candidates with the highest modes (expected vote shares). In particular, we hypothesize that the winner of the 2007 presidential election will be the candidate of these two whose mode is closer to the overall median voter. 
Abstract. We make use of a novel forecasting technique based on the Hotelling-Downs spatial framework to project vote outcomes in the second round of the two-round French presidential election system. In doing so we take advantage of the high degree of bimodality in the distribution of voter preferences to predict which candidates will make it into the second round. While our principal focus is on the 2007 election, we also look at the seven previous presidential elections in the French Fifth Republic, from 1965 through 2002.

Résumé. Pour prédire le résultat du deuxième tour de scrutin des élections présidentielles françaises de 2007, nous avons fait appel à une nouvelle technique fondée sur le modèle spatial de Hotelling-Downs. En procédant ainsi, nous avons pris en compte le haut degré de bimodalité de la distribution des préférences pour pronostiquer lequel des deux candidats remporterait la victoire. Bien que nous ayons surtout centré notre attention sur l'élection présidentielle de 2007 , nous avons aussi examiné les sept élections présidentielles antérieures de la Cinquième République, tenues de 1965 à 2002, afin de tester notre méthode et prédire ex ante les résultats de 2007.

The paper is organized as follows. The next section focuses on the way we apply the median voter model to the French case; the succeeding section presents a graphical overview of French presidential elections since 1965 , along with a brief discussion of each. The final substantive section presents the forecasts. The projected percentage of votes for the left candidate at the second round is calculated by using a bivariate regression equation with proximity (in terms of percentage of votes) to the overall median voter as the key independent variable. The prediction was done one month before the election.

We conclude the paper with a brief overview of our findings and of how they fit with other research on election prediction.

\section{The Spatial Median Voter Model Applied to the French Case.}

We make use of a stylized picture of French party space, in which we identify in each election five political groupings: extreme left, left, centre, ${ }^{3}$ right and extreme right. This picture is clearly a simplification and avoids the creation of a separate (anti-) immigration dimension on which Le Pen might be located. ${ }^{4}$ This one-dimensional portrait of French political competition is, nonetheless, so much in accord with the way French journalists and political scientists have analyzed the past four decades of French politics that we feel quite comfortable in making use of it. ${ }^{5}$ It seems to capture the basic elements of presidential competition over this period. And, since the presidential election is such a critical feature of the French political system (Lijphart, 1999), even though we restrict ourselves to presidential elections, we still can capture key features of the changes in political competition in France.

Our approach is based on three underlying hypotheses:

(1) First, we assume that citizens vote sincerely for their preferred candidate and not tactically, that is, votes represent actual preferences. ${ }^{6}$ 
Similarly, we take candidates as responding to voters' sincere preferences.

(2) Second, we do not consider attempts to manipulate the voting system by fostering divisions among one's own or the opposition bloc.

(3) Third, we posit that candidate positions can be identified along a left-right axis.

The first assumption is plausible because, in general, the two-round structure of voting lowers the cost to voters when casting sincere votes for the party closest to their ideology as long as voters can expect that a party close to their preferences will make it into the final competition. The second assumption seems accurate for all but possibly the election that led to the first Mitterand victory. The assumption of unidimensionality is a common one. Locating parties on the left-right dimension is facilitated because we are aggregating votes in a quintile classification from extreme left to extreme right. Much of the time we may assume that the relative location of our five groupings along the ideological dimension remains roughly constant in that French political parties are heavily constrained by their historically defined relative location in the ideological space and by the preferences of a party activist base which tend to anchor the parties in ideological terms, particularly on the left side of the political spectrum. Nevertheless, on the right side of the political spectrum there can be party movement between the right and the centre-right in terms of whether the UDF or the Gaullists are further to the right. To deal with this problem we look more specifically at the political platform and political campaign of the candidates in each of the elections. In situations where there may be doubt, we will consider alternative locations, and check the impact of our locational estimates on the accuracy of our prediction.

We now turn to the distribution of votes at each presidential election since 1965 across the five blocs (see appendix A) - identifying both overall and within-bloc median and modal locations.

\section{Analyses of Individual Presidential Elections}

\section{(a) The 1965 Presidential Election}

Figure 1(a) illustrates the initially bimodal nature of the French political system. ${ }^{7}$ The vertical line indicates the overall median; the lines with arrows the medians of the two tendances. The modes which coincide with the two high points represent the most popular candidates or parties.

Mitterrand, as the leader of a coalition of both Socialists and Communists, ran for the left, while Lecanuet was the leader of the centre party. De Gaulle as the representative of the neo-conservative party was 
Figure 1(A)

Distribution of Votes in the First Round of the Presidential Election of 1965. (Also shows location of overall median voter and the median voters in the left bloc and the right bloc.)

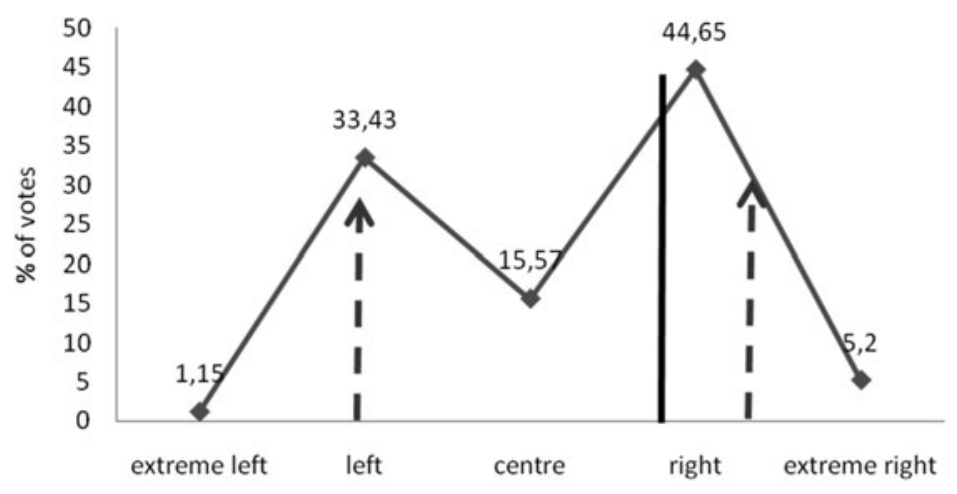

the closest to the overall median voter in the second round (a distance of 0.2 per cent versus a distance of 15.3 per cent for Mitterrand), and he won. In 1969, De Gaulle resigned early after a referendum in which his proposal was defeated. This resulted in an early presidential election (before the seven-year term then in effect had expired).

\section{(b) The 1969 Presidential Election}

Pompidou was the candidate of the neo-conservative Gaullists and captured 44.5 per cent of the votes on the first round. The Communist party, with Duclos received 21.27 per cent of the votes, and the parties on his left (whose candidates were Krivine, Ducatel and Rocard) reached 26.6 per cent of votes in toto, while the Socialist party, with Deferre as its candidate, scored a meagre 5 per cent of the vote. The centrist party, with Poher, the President of the Senate, as its candidate, did well, with 23.3 per cent of votes. Its position almost perfectly coincides with the location of the overall median voter.

Poher was arguably the median choice. Even though he received only 23.3 per cent of the first round vote he still was able to enter the runoff, and he should have won the second round of the election. But Duclos asked the Communists not to vote for Poher, and to abstain instead. Poher lost on the second round because the level of abstention from extreme left-wing electors was so high. This abstention shifted the overall median voter among the actual second-round electorate rightward, so Pompidou won. 
FiguRe 1(в)

Distribution of Votes in the First Round of the Presidential Election of 1969. (Also shows location of overall median voter and the median voters in the left bloc and the right bloc.)

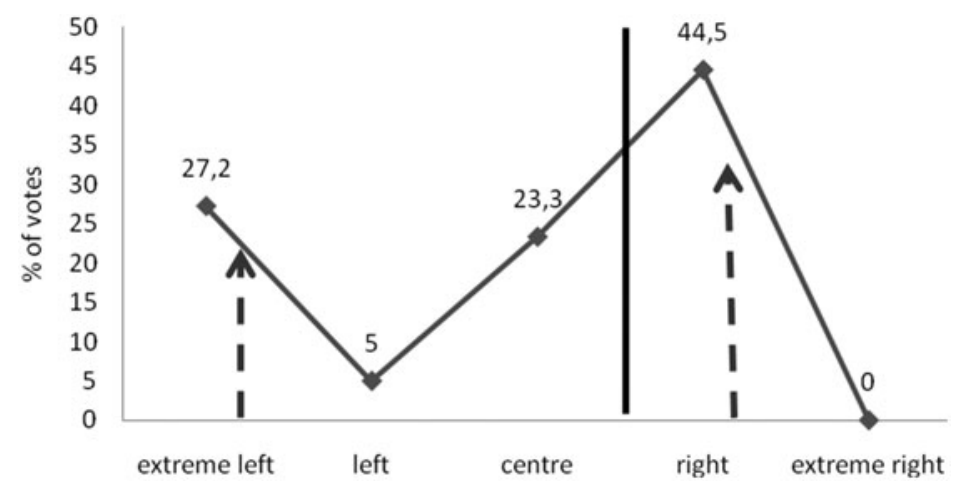

\section{(c) The 1974 Presidential Election}

Pompidou died before the end of his mandate and a new election took place, again prematurely, in 1974. As Figure 1(c) shows, the shape of the distribution of votes changed drastically in the 1974 presidential election from that in the 1969 election; it became unimodal with the highest mode on the left of the political scale. The distribution is skewed toward the left, with the median voter almost exactly at the centre.

FiguRE 1(c)

Distribution of Votes in the First Round of the Presidential Election of 1974. (Also shows location of overall median voter and the median voters in the left bloc and the right bloc.)

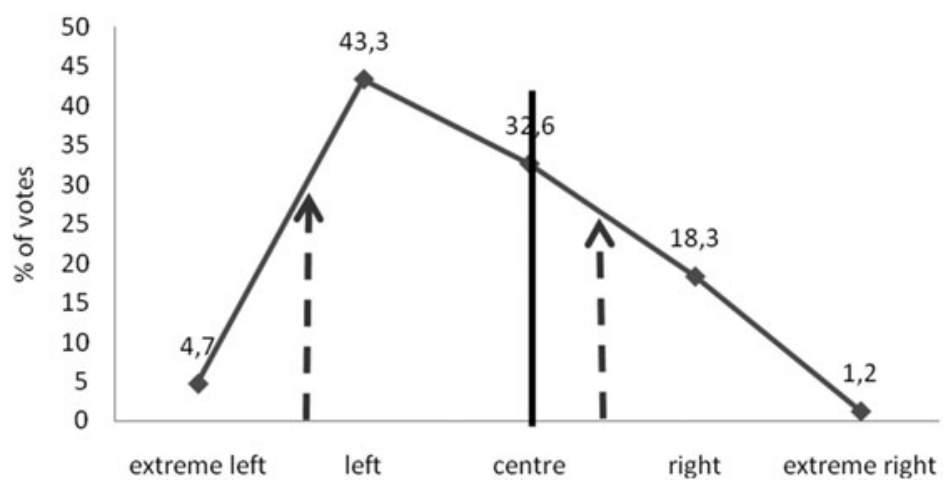


Mitterrand formed a coalition with the Communist party and the centre-left, while the right-wing parties were divided between the centreright party of Valéry Giscard d'Estaing (VGE) and the Gaullist party with Chaban Delmas as its candidate. VGE, in a famous speech at Nantes, declared his own position to be a centrist one. VGE defeated his rival on the right, Chaban-Delmas, in the first round ${ }^{8}$ and won the second-round election, as his perceived location was the closest to the median voter, indeed essentially identical to it.

\section{(d) The 1981 Presidential Election}

Seven years later, at the end of VGE's term in office, a new election was required. The shape of the distribution of votes was again changing; in 1981 it became multimodal and quasi-uniform with four blocs of nearly equal size, two on the left, one in the centre, and one on the right. The overall median voter was located just on the left. On the extreme right no candidate was running. Mitterrand won, as his position was virtually indistinguishable from that of the overall median voter (a distance of 0 per cent versus a distance of -0.70 per cent for VGE).

\section{(e) The 1988 presidential election}

With the passage of another seven years, the shape of the distribution of votes was further altered. The main change was a much strengthened far right, although the overall distribution is still bimodal ${ }^{9}$ and still skewed to the left. ${ }^{10}$

Figure 1(D)

Distribution of Votes in the First Round of the Presidential Election of 1981. (Also shows location of overall median voter and the median voters in the left bloc and the right bloc.)

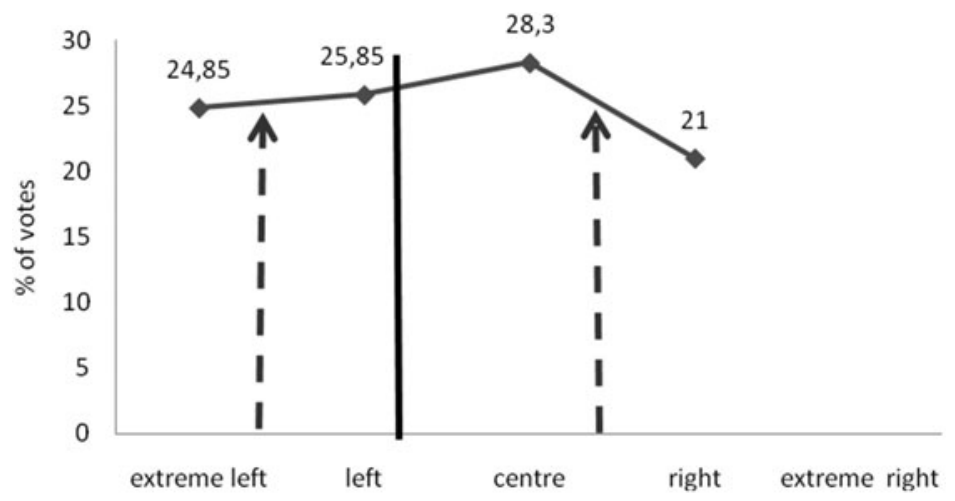


FigURE 1(E)

Distribution of Votes in the First Round of the Presidential Election of 1988. (Also shows location of overall median voter and the median voters in the left bloc and the right bloc.)

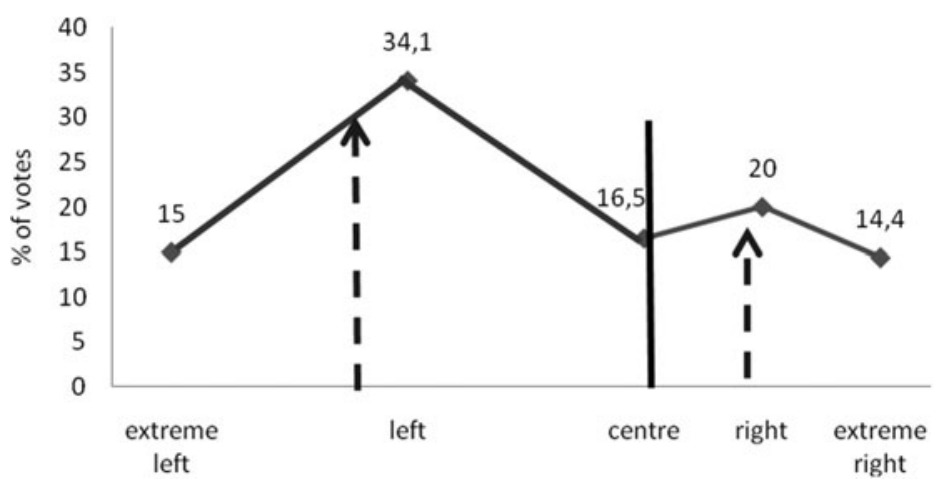

The position of the median voter is just at the centre. If we sum up votes, starting on the extreme right: Le Pen (FN) 14.4 per cent, at the extreme right, Jacques Chirac (RPR) on the right 20 per cent, and Raymond Barre (RPR) at the centre right, ${ }^{11} 16.5$ per cent, the total is 50.9 per cent of votes. The left and extreme left total 49.1 per cent of votes. Both modes were close to the median voter. But Jacques Chirac, though he was the closest to the median voter of the right-wing voters, was not the closest to the overall median voter. Mitterrand was the closest to the overall median voter. Moreover, if Jacques Chirac were to have courted the overall median voter by moving to the left, then he would have lost votes on his extreme right. In fact many voters of the Front National deserted Jacques Chirac.

Le Pen's success in 1988 can in part be attributed, we believe, to the effects of some political machinations by President Mitterrand. On the one hand, we believe that Mitterrand was seeking to use the populist appeal of Jean-Marie Le Pen as a weapon against both the centre-right Union pour la Democratie Francaise (UDF) and the Gaullist Rassemblement pour la République (RPR) coalition. Those sympathetic to the left in the media insured that Le Pen was provided access to public TV channels' political programs, but commentators also insured that no right-wing coalition with Le Pen was possible by making a "political correctness" argument that Le Pen was too far out of the political mainstream to be a suitable coalition partner. On the other hand, while it is generally thought that a degree of proportional representation was introduced in the 1985 parliamentary elections by Mitterrand to save the Socialist party from what was feared might be a potentially disastrous parliamentary election defeat under the 
two-round systems (Bréchon, 1998), this change in electoral rules also made it easier for the extreme right-wing to gain parliamentary representation that year-thus strengthening Le Pen's hand in the subsequent presidential election.

\section{(f) The 1995 Presidential Election}

In 1995 the shape of the distribution of votes is multimodal, with five ideological blocs of nearly equal size.

The political platform of Chirac was clearly on the centre left, with an emphasis on the "fracture sociale," while Balladur, who was the prime minister and of the same party as Chirac, was customarily located at the centre right. Thus, we have placed Balladur to the right of Chirac in this election. ${ }^{12}$ Chirac gained sufficient votes to enter the second round, and he won the second round since his platform was virtually coterminous with the views of the median voter. Note, also, however, that the far right continued to gain ground in the first round.

\section{(g) The 2002 Presidential Election}

The shape of the 2002 distribution of votes has similarities to that of much earlier elections, with a splintered left and a strong Gaullist right. However, the growth in strength of candidates on both the far left and the far right, ${ }^{13}$ and the splitting of votes on the left meant that Jospin, the candidate of the Socialist party, was not selected at the first round because

FiguRE 1(F)

Distribution of Votes in the First Round of the Presidential Election of 1997. (Also shows location of overall median voter and the median voters in the left bloc and the right bloc.)

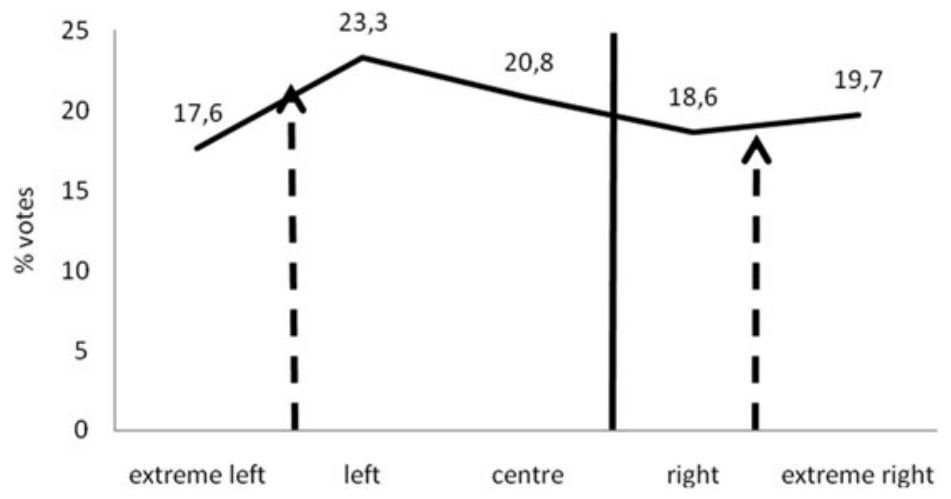


FiguRE 1(G)

Distribution of Votes in the First Round of the Presidential Election of 2002. (Also shows location of overall median voter and the median voters in the left bloc and the right bloc.)

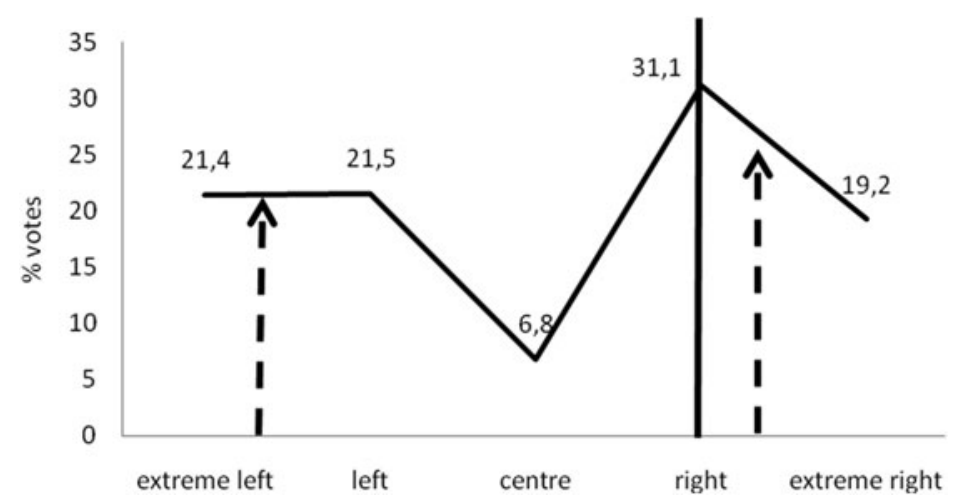

he put his platform close to the overall median voter and not close to the median voter of his own camp, leading to dissatisfaction with him by voters on the left. In 2002 we had a contest between a rightist candidate, Chirac, and a far-right candidate, Le Pen. Endorsed reluctantly by Jospin, Chirac won the second round in a landslide, with Le Pen doing little better on the second round than he had in the first. (Note that the table shows aggregated votes for the left and the extreme left; Chirac and Le Pen were the two candidates with highest votes on the first round.) ${ }^{14}$

\section{(h) The 2007 presidential election.}

The change in the shape of the distribution of votes over the new fiveyear presidential term of office is once again quite considerable. In particular, there is a shift away from the extreme left and the extreme right, and a strong gain for a centrist party.

The distribution is multimodal, with the two largest modes on the left and on the right, respectively. This distribution is relatively similar to the one in 1965. In the second round, Sarkozy was the candidate closest to the median voter of the overall distribution, and he won. However, Bayrou, arguably the centrist, would have defeated either left-wing or right-wing candidates had he received enough first-round support to enter the second round of the election (Abramson, 2007).

With this historical background suggesting the plausibility of viewing second-round outcomes as a choice between two modal candidates whose outcome is decided by which is closer to the overall median voter, we turn to our ex ante prediction of the 2007 presidential election. 


\section{Impacts of Mode Locations on the French Presidential Election Outcomes and the Forecast for the 2007 Presidential Election.}

To forecast the winner of the 2007 French presidential election, we focus on the location of the two highest modes relative to the location of the overall median voter in the first round. As noted earlier, we look at the distribution of intended votes revealed by opinion surveys one month before the election, but with a correction for past systematic bias in the survey data.

Our problem was to estimate the distribution of Figure 1(h) based on opinion polls taken one month before the election (or even earlier). To deal with this issue, from 1981 to 2007 we projected intended votes based on opinion polls of TNS-SOFRES 6, 5, 4, 3, 2 and 1 weeks before

FigURE 1(H)

Distribution of Votes in the First Round of the Presidential Election of 2007 (also shows location of overall median voter and the median voters in the left bloc and the right bloc) of forecast and of ex post results.
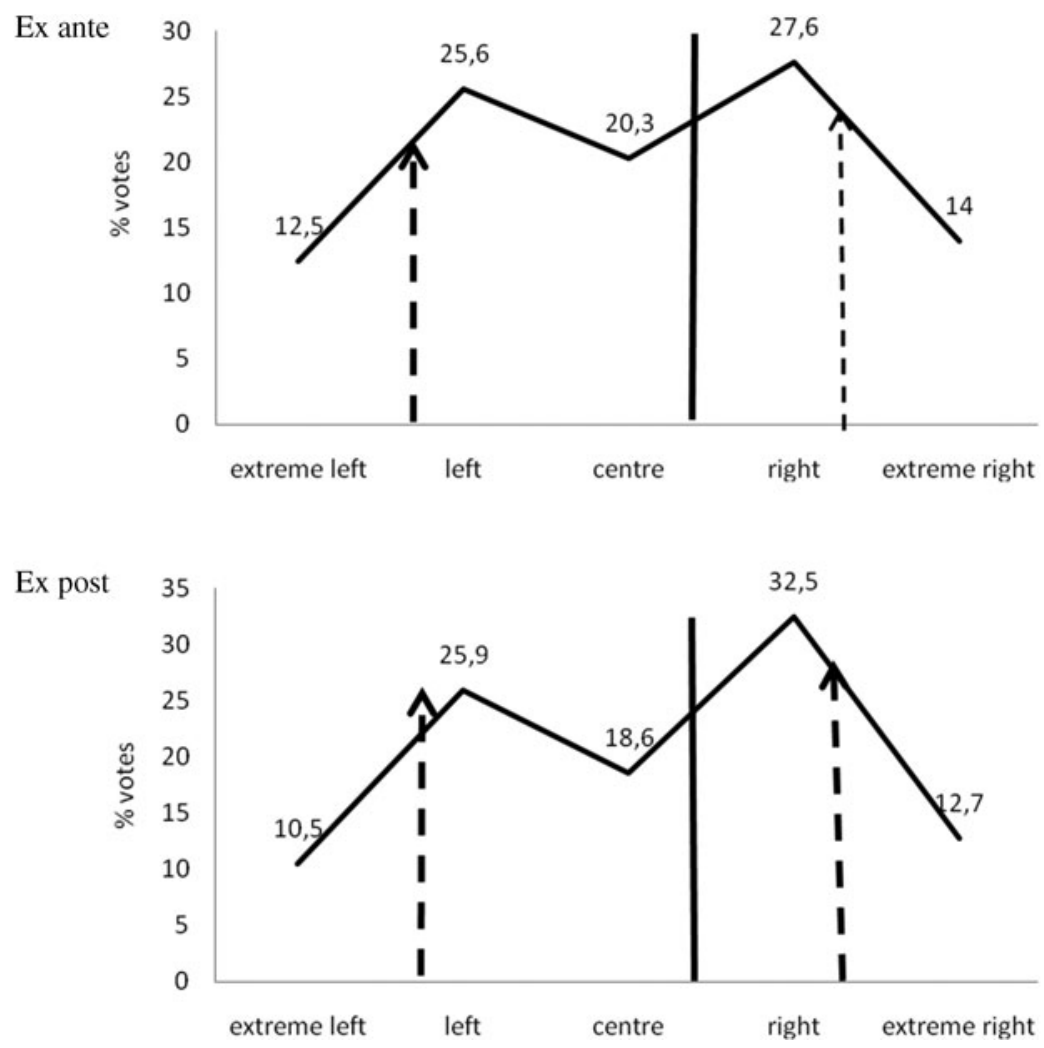
the election. ${ }^{15}$ We then compared these estimates, especially those done four to six weeks in advance of the election, to the actual results of the elections for each presidential election. We decomposed prediction errors into systematic bias and hazard-based errors, using Theil's (1966) decomposition of errors methodology. Then we eliminated the systematic bias to obtain a distribution of intended vote which contains only hazard errors (see appendix B for details).

For each election between 1981 and 2007 we calculated this corrected distribution of votes and identified the two highest modes. The candidates located at these modes were our predictions for the two candidates running in the second round. We also calculated the distance of each mode to the overall median voter. Then we predicted the winner among these two projected candidates as the one closer to the overall median voter. For the 1965, 1969 and 1974 elections, where we did not have survey data, we used the actual results of the first round of the election. Table 1 presents our electoral predictions based on this method.

Table 1 shows that, with the notable exception of 2002, opinion polls, whether corrected or not via Theil's (1966) methodology, predicted quite well the two highest modes. Theil's statistical correction method is, however, useful in more accurately predicting the distances to the overall median voter, and thus the winner on the second round. Making our projections one month in advance, in 2007 our statistically corrected estimates did a good job approximating the difference of votes between the left (Ségolène Royal) and the centre (Bayrou). On the other hand, we underestimated the vote for Sarkozy and overestimated the votes for the extreme left and right. But these estimation errors are sufficiently minor that they are without consequences for our predictive ability to identify the two highest modes, or, as we shall see, to impact on our ability to predict the final winner.

To predict the percentage of votes of the candidate of the left (or the right) at the second round in 2007, we estimated from past elections the relation between the distances of the mode of this candidate to the overall median voter. Then we ran a bivariate regression with distance as our independent variable. Table 2 presents the data used for this simple regression.

The relationship between vote share and distance to the median voter is depicted graphically in Figure 2(a) for the left-wing candidate in the second round (if any) and in Figure 2(b) for the mainstream right-wing candidate in the second round.

With a distance of 11.9 per cent between the left mode and the overall median voter, our regression estimate based on the previous elections for which we have the relevant data was that Ségolène Royal should get 46.73 per cent of the second-round vote (here we simply insert 11.9 per cent into the equation). Taking standard errors into account, we predicted that the vote share of Madame Royal would be between 44.7 per cent and 
Figure 2 (A)

$\%$ of Votes of the Left-Wing Leader at the Second Round: For Years 1965, 1974, 1981, 1988, 1995

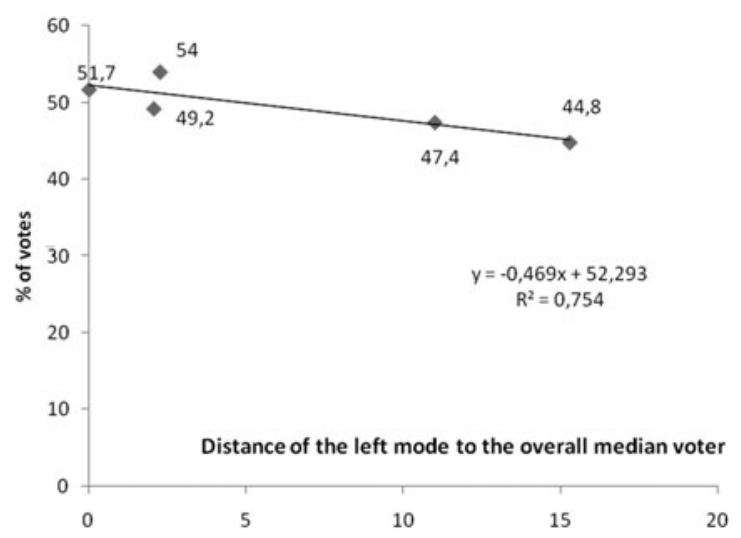

Vote for the left (second round) $=52.3-0.468$ (distance of the left mode to the median) $\mathrm{t}$ statistic $39.5-3.032 ; \mathrm{R}^{2}=0.75$; Adjusted $\mathrm{R}^{2}=0.67$, standard error $=2.05$

48.7 per cent. In fact, she received a vote share of 46.9 per cent; thus our estimates of 46.73 came within 0.17 per cent of the true result.

Doing the same analysis to project the vote share of the right-wing leader gives the results shown in Figure 2(b). Despite the poor regression fit of the regression equation shown in Figure 2(b), with an adjusted

Figure 2(B)

Percentage of Votes of the Right-Wing Leader at the Second Round for Years 1965, 1969, 1974, 1981, 1988, 1995, 2002

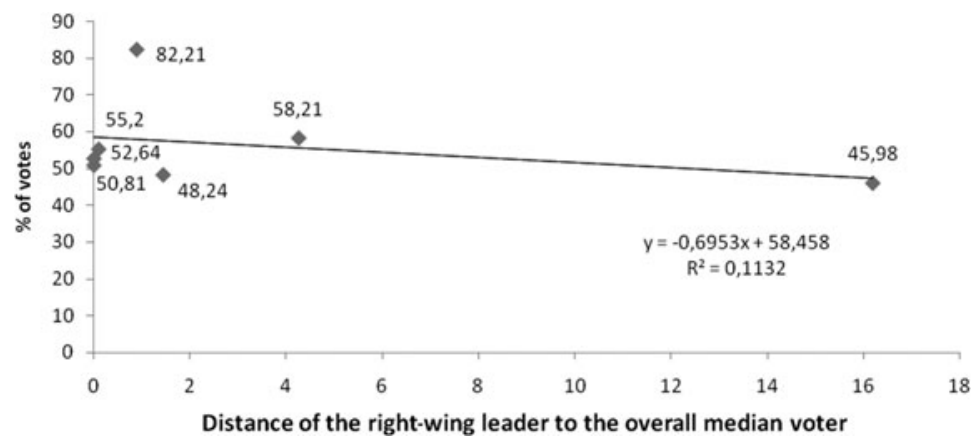

Vote for the left (second round) $=52.3-0.468$ (distance of the left mode to the median) t statistic $39.5-3.032 ; \mathrm{R}^{2}=0.75$; Adjusted $\mathrm{R}^{2}=0.67$, standard error $=2.05$ 
TABLE 1

Projected second-round winner from vote intentions one month before elections versus actual election results

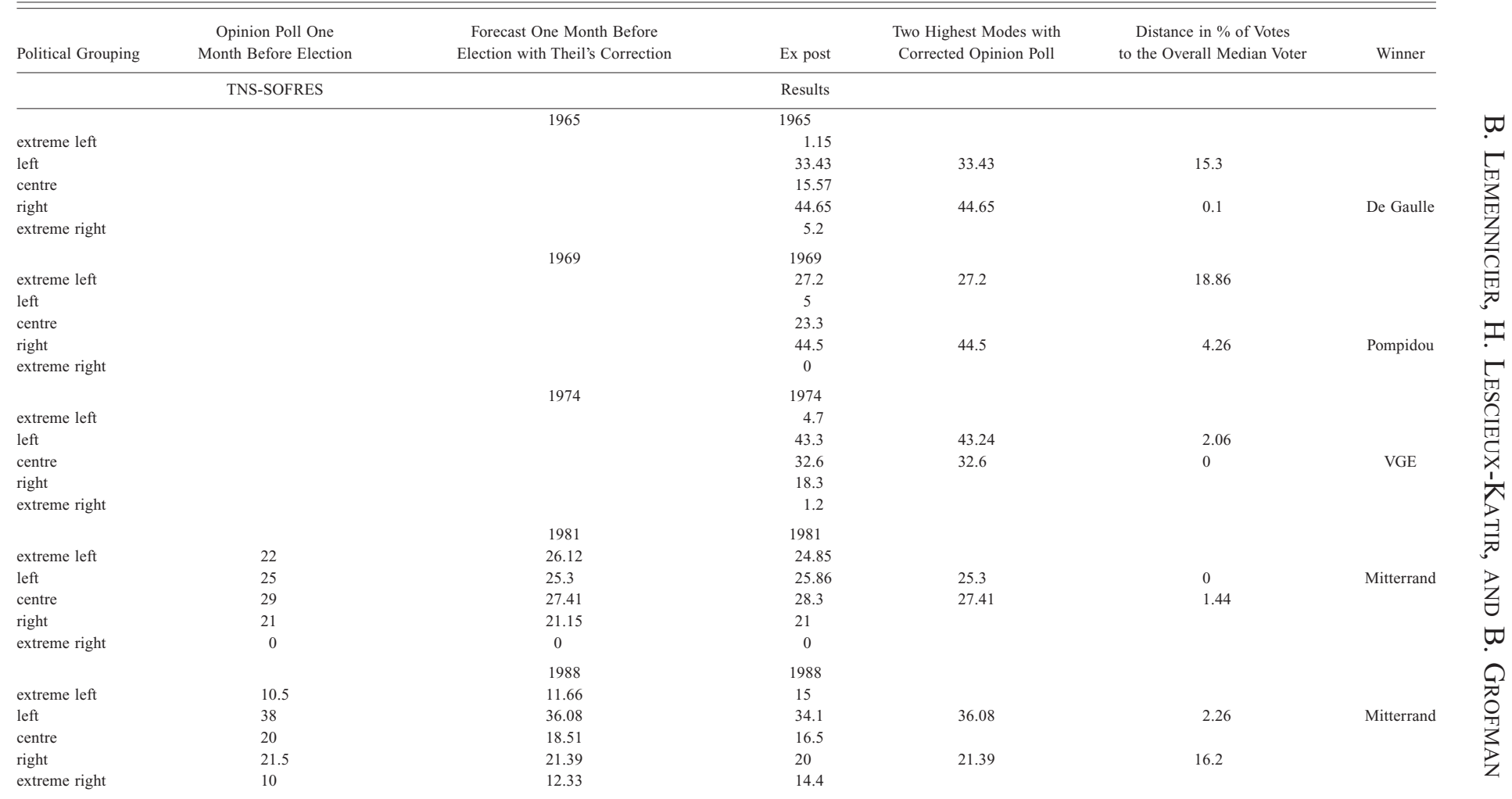


1988*

extreme left

left

centre

right

extreme right

extreme left

left

centre

right

extreme right

extreme left

left

centre

right

extreme right

extreme left

left

centre

right

extreme right

extreme left

left

centre

right

extreme right switch between right and centre right location

11.66

21.39

16.5

12.33

1995

17.9

21.09

24.99
21.07

14.93

$1995^{*}$

Chirac

14.4

1995

17.6

23.3

20.8

19.7

switch between right and centre right

$\begin{array}{ll}17.9 & 17.54 \\ 21.09 & 23.3 \\ 21.07 & 20.84 \\ 24.99 & 23.32\end{array}$

(1)

17.54

23.3
20.84

23.32

15

14.93

2002

21.4

21.5

6.8

31.1

19.2

$2007^{* * *}$

(10.5)

$(25.9)$
$(18.6)$

$(18.6)$
$(32.5)$

$(32.5)$
$(10.2)$

*To test the robustness of the method we switch the centre right and the right in 1988 and in 1995. In each of these years the relative location of the two major candidates on the right wing is debatable. In 1995, even with a switch, Chirac still wins, as he remains the closer to the overall median voter than his left-wing opponent. But in 1988 the model predicts Chirac as the closest, but Mitterrand won. In that case the rate of failure in the prediction is 1 out of 8 . This illustrates the difficulty mentioned earlier in the text.

**Here the two highest modes were Chirac and Le Pen. The grouping of political parties on the left masks the elimination of Jospin, the Socialist leader, at the first round. Nevertheless Chirac is the closest candidate to the overall median voter, and won the election against a rival at the extreme right in a way that does not violate the median voter pivotal power prediction of the Downsian model.

***At the time the initial French version of this paper was written, the results were unknown [see Lemennicier, B. and H. Lescieux. 2007].

Our prediction is based on our column in italics. We present the actual results in bold and in parenthesis. We would emphasize that in 2007 as in all years since 1981 , our prediction was ex ante and not ex post. 


\section{TABLE 2}

Relation between percentage of votes at the second round of the leftand right-wing leaders and the estimated distance of their mode at the first round with the overall median voter through all presidential elections

\begin{tabular}{lcccc}
\hline \hline & $\begin{array}{c}\text { \% Votes at the } \\
\text { Second Round } \\
\text { of the Left } \\
\text { Wing Leader }\end{array}$ & $\begin{array}{c}\text { Distance of the } \\
\text { Highest Left Mode } \\
\text { to the Overall } \\
\text { Median Voter* }\end{array}$ & $\begin{array}{c}\text { \% Votes at the } \\
\text { Second Round } \\
\text { of the Right } \\
\text { Wing Leader }\end{array}$ & $\begin{array}{c}\text { Distance of the } \\
\text { Highest Right Mode } \\
\text { to the Overall } \\
\text { Median Voter* }\end{array}$ \\
\hline 1965 & 44.8 & 15.3 & 55.2 & 0.1 \\
1969 & - & - & 58.2 & 4.3 \\
1974 & 49.2 & 2.1 & 50.8 & 0 \\
1981 & 51.7 & 0 & 48.2 & 1.4 \\
1988 & 54 & 2.3 & 46.0 & 16.2 \\
1995 & 47.4 & 11.0 & 52.6 & 0 \\
2002 & - & - & 82.2 & 8.4 \\
2007 & 46.7 & 11.9 & 52.6 & \\
$2007 * *$ & 46.9 & & 53.06 & \\
\hline
\end{tabular}

*Drawn from Table 1; **estimated by our simple regressions

$\mathrm{R}^{2}$ of only .064 , and a t statistic of only 0.8 for the independent variable, well below statistical significance, we could still use this regression to successfully project the winner in 2007. With a distance of 8.4 per cent between the right mode and the overall median voter, our regression estimate based on the previous elections for which we have the relevant data was that Nicolas Sarkozy should get 52.6 per cent of the second-round vote (here we simply insert 8.4 per cent into the equation). In fact Sarkozy received a vote share of 53.06 per cent; thus our estimates was within 0.46 per cent of the true result. Note, too, that although we ran separate regressions for each of the two second-round candidates in 2007, the estimated second-round vote shares of both candidates add almost perfectly to 100 per cent $(99.3$ per cent).

\section{Conclusion}

The French double ballot electoral structure makes it likely that multiple candidates will contest the first round. Parties at the first round can try to influence the policies of existing parties able to govern by showing their strength with the voters. Voters of the two basic camps (tendances) in French politics, the left and the right, are concerned to assure that a candidate from among their own tendance will be among the two candidates who make it into the final round. In practice, until the anomaly of the 2002 election, however, where dispersal of the votes on the left and on the right made the distribution of votes among the five blocs we have identified very 
close to a uniform distribution, and led to a contest between a candidate of the right (Chirac) and a candidate of the ultra-right (Le Pen), the strength of the leading parties in each of the two tendances made the distribution of votes look bimodal viv-à-vis the left plus extreme left versus the right plus extreme right. This bimodality has more or less guaranteed that a representative of the right would face a representative of the left in the runoff.

The second round of the French two-ballot system constrains the two parties who make it to that round to appeal to a broader set of voters, including the median voter, and to form alliances with other parties in order to win the second round. In general, the winner of the election will be the leader of the camp whose own median and/or modal voter is closest to the overall median voter. Thus, the double ballot electoral system imposes a constraint on the strategy of political leaders who recognize the ultimate importance of the overall median voter. They must avoid the danger of being so oriented to winning the eventual two-candidate second round that they are eliminated at the first round, since when a candidate of the right wing (the left wing) shifts his or her political platform in the direction of the overall median voters, he can expect to lose votes to more extreme parties of his/her own tendance. Outcomes in the double ballot system are thus simultaneously affected by the location of the overall median voter and by the nature of the within-bloc distribution of voter support-in particular, by which bloc's modal party is closer to the overall median voter.

We have built a predictive model for French presidential elections based on these strategic factors affecting party incentives in a two-round competition, and simplifying assumptions about French political competition in terms of a left-right space and five "families" of contestants in a way that is familiar to all commentators on French politics. Testing that median voter spatial model with estimates drawn from analyses of a number of previous presidential elections, we were able to come up with a very good prediction of the 2007 presidential outcome in terms of who will be in the second round and who will win.

\section{Notes}

1 Also see Auberger (2007); Jérôme and Jérôme-Speziari (2007a); Jérôme and JérômeSpeziari (2007b); Lafay and others (2007).

2 Formerly called SOFRES, it is a French polling organization created in 1963 by Pierre Weill. It is a part of the Taylor Nelson Sofres international group of consulting, marketing and polling organizations.

3 However, we would emphasize that what we are labeling as the centre, is in fact the centre right; the centre left merged with the Socialist party between 1969 and 1974, during Pompidou's term as president, and no real centre-left party ever subsequently reemerged. Thus, when we view French politics in terms of two blocs (tendances) we treat the centre as a component of the right; but when we do a three-bloc model, the centre is treated as a distinct entity. 
4 This problem of dimensionality is particularly acute for the National Front, since many authors have suggested that it cannot be viewed as positioned at the extreme right, but should be located in a two-dimensional space; see, for example, Roemer (1999); Lee and others (2006). These authors introduce a two-dimensional spacewith taxation or size of public sector on one dimension and immigration on the other dimension. Insofar as immigrants are expected to benefit from state largesse, antiimmigration sentiments and the usual left-right dimensions of attitudes toward the welfare state coincide, but they propose that there are also "fairly poor racist voter" who benefit from more public sector spending but who abhor alien immigrants because of their racial or ethnic differences with the host country population. Other twodimensional representations of French political space include Perrineau and others (2000) and Adams and others (2005)

5 Other recent work, such as Abramson (2007), which looks exclusively at the 2007 French presidential election, also uses a unidimensional model of French politics.

6 For discussion of the distinction between sincere and strategic voting see Blais (2004).

7 Downs (1957) also calls attention to bimodality in France, but during the time period to which he was referring, France was operating under a proportional representation electoral structure, with a strong Communist party on the extreme left.

8 The Gaullist party was clearly to the right of VGE, but on the first round, ChabanDelmas as a candidate offered a political platform opting for a "new society" which placed him at the left of VGE and close to the centre-left location of the Mitterrand coalition. Located too far from his own party, Chaban Delmas lost more votes from his own voters than he gained from voters who were close to Mitterrand, and thus failed to make the runoff.

9 This case illustrates the difficulty, mentioned earlier, in establishing the relative locations of the candidates of the two main right-wing parties. Bimodality comes from the fact that we locate Raymond Barre on the centre right, rather than to the right of Chirac. Switching the locations of Barre and Chirac so as to place Barre to Chirac's right does not affect Jacques Chirac's selection on the second round, since he is still the candidate of the right with the most votes. But with Jacques Chirac at the centre right the distribution now is unimodal. Switching the locations of Barre and Chriac does affect which candidate is the closest to the overall median voter, and thus which is the Condorcet winner. With this reversal, Chirac becomes the closest to the overall median voter, and our spatial median voter prediction would fail.

10 Mitterrand won as the candidate in the second round who was closer to the overall median voter.

11 Raymond Barre is clearly at the centre right, as suggested by Bréchon (1998). But we follow this traditional point of view on Barre's ideological location not for the reason advanced by Brechon, that is, the centre-right voters chose to support Barre over Chirac, but because, when he served as a prime minister under the presidency of VGE, we viewed Barre as having taken a centrist stance

12 Switching the locations of Balladur and Chirac so as to place Balladur to Chirac's left does not affect Jacques Chirac's selection for the first round, since he is still the candidate of the right with the most votes. Nevertheless, with this placement of the relative positions of the two right-wing candidates, Chirac would always be the choice of the median voter as he is always the closest to the overall median voter. But, based on our analysis of campaign statements, we believe that locating Chirac to the right of Balladur is the correct placement in this election.

13 As suggested by Lafay (1994), in the 1990s, presidential competition was already becoming more and more fragmented, making the outcomes of the election more uncertain.

14 The strength of blocs on both the far left and the far right who rejected the proEuropean Union stance of the governing party was shown in the referendum on the 
EU treaty in 2005, in which the treaty was rejected by French voters; see Lemennicier (2005).

15 We use data from this Institute because of the availability of past data from it which were collected in a consistent way and presented in a consistent format.

\section{References}

Abramson, P.R. 2007. "The French Presidential Election of 2007: Was Sarkozy the Condorcet Winner?" French Politics 5 (8): 287-291.

Adams, J., S. Merrill and B. Grofman. 2005. A Unified Theory of Party Competition: A Cross-National Analysis Integrating Spatial and Behavioral Factors. New York: Cambridge University Press.

Auberger, A. 2007. "Economy, Politics and Results of the French Presidential Elections." Paper presented at LAEP Paris I, Public Choice Society World Meeting. Amsterdam.

Blais, Andre. 2004. "Strategic Voting in the 2002 French Presidential Election." In The French Voter: Before and After the 2002 Elections, ed. Michael Lewis-Beck. Houndmills UK: Palgrave Macmillian.

Bréchon, P. 1998. "La France Aux Urnes" Les études de la Documentation française, Paris, La Documentation Française.

Cox, G. W. 1997. Making Votes Count: Strategic Coordination in the World's Electoral Systems. New York: Cambridge University Press.

Downs, A. 1957. An Economic Theory of Democracy. New York: Harper \& Row.

Hotelling, H. 1929. "Stability in Competition." The Economic Journal 39: 41-57.

Jérôme, Bruno and Véronique Jérôme-Speziari 2007a. "Présidentielle: ce que prévoit la simulation des économistes." l'Expansion, (Paris) janvier, $\mathrm{n}^{\circ} 715$.

Jérôme, Bruno and Véronique Jérôme-Speziari 2007b. "Simulation Politico-économique de la Présidentielle de 2007." Working Paper, IRGEI University of Paris Panthéon-Assas.

Lafay, J. D. 1994. "Faut-il supprimer l'election du Président de la République au suffrage universel?" Le Figaro (Paris), Cheminement du futur, 29 décembre.

Lafay, J. D., F. Facchini and A. Auberger. 2007. "Modèles politico-econométrique et prévisions electorales pour mai 2007." Revue Française d'Economie 4 (21): 5-23.

Lee, J., J. Roemer and K. Van der Straeten. 2006. "Racism, Xenophobia and Redistribution." Journal of the European Economic Association 4: 446-54.

Lemennicier, B. 2005. "Political Polarization and the French Rejection of the European Constitution." European Journal of Political Economy 21: 1077-84.

Lemennicier, B. 2007. "How good were the forecasts of the May 2007 French presidential election?" Mini-symposium on forecasting French 2007 presidential election. IRGEI University of Paris Panthéon-Assas, May 3.

Lemennicier, B. and H. Lescieux. 2007. "Peut-on Prédire le Résultat des Elections Présidentielles d'avril 2007 à Partir de la Distribution des Intentions de Votes le Long d'un Axe Politique Gauche-Droite?" Working paper, IRGEI, University of Paris II, Panthéon-Assas, March.

Lijphart, A. 1999. Patterns of Democracy: Government Forms and Performance in ThirtySix Countries. New Haven CN: Yale University Press.

Nordhaus, W.D. 1975. "The Political Business Cycle." Review of Economic Studies 42(4): 169-90.

Perrineau, P., J. Chiche, B. Le Roux and H. Rouanet. 2000. "L'Espace politique des electeurs français à la fin des Années 1990: Nouveaux et anciens clivages, hétérogénéité des electoratsé." Revue française de science politique 50 (3): 463-88.

Roemer, J. 1999. "The Democratic Political Economy of Progressive Taxation." Econometrica 67: 1-19.

Theil, H. 1966. Applied Economic Forecasting. Amsterdam: North-Holland. 
APPENDIX A

Distribution of the candidates by political families for the French Presidential elections from 1974 till 2007

\begin{tabular}{|c|c|c|c|c|c|}
\hline & Extreme left & Traditional left & Centre & Traditional right & Extreme right \\
\hline 1965 & Michel Barbu & $\begin{array}{l}\text { François Mitterrand } \\
\text { Pierre Marcilhacy }\end{array}$ & Jean Lecanuet & Charles de Gaulle & Jean Louis Tixier Vignancourt \\
\hline 1969 & $\begin{array}{l}\text { Jacques Duclos } \\
\text { Michel Rocard } \\
\text { Alain Krivine } \\
\text { Louis Ducatel }\end{array}$ & Gaston Deferre & Alain Poher & Georges Pompidou & - \\
\hline 1974 & $\begin{array}{l}\text { Arlette Laguiller } \\
\text { Emile Muller } \\
\text { Alain Krivine } \\
\text { René Dumont }\end{array}$ & François Mitterrand & Valéry Giscard d'Estaing & $\begin{array}{l}\text { Jacques Chaban-Delmas } \\
\text { Jean Royer } \\
\text { Jean-Claude Sebag } \\
\text { Guy Héraud } \\
\text { Bertrand Renouvin }\end{array}$ & Jean-Marie Le Pen \\
\hline 1981 & $\begin{array}{l}\text { Arlette Laguiller } \\
\text { Georges Marchais } \\
\text { Brice Lalonde } \\
\text { Huguette Bouchardeau } \\
\text { Michel Crépeau }\end{array}$ & François Mitterrand & Valéry Giscard d'Estaing & $\begin{array}{l}\text { Jacques Chirac } \\
\text { Michel Debré } \\
\text { Marie-France Garaud }\end{array}$ & \\
\hline
\end{tabular}


Pierre Boussel

André Lajoinie

Pierre Juquin

Antoine Waechter

Arlette Laguiller

Jacques Cheminade

Robert Hue

Dominique Voynet

2002 Arlette Laguiller

Daniel Gluckstein

Olivier Besanceno

Christiane Taubira

Noël Mamère

Robert Hue

Jean-Pierre Chevènement

2007 Arlette Laguiller

Olivier Besancenot

José Bové

Marie-George Buffet

Dominique Voynet

\section{François Mitterrand \\ Raymond Barre}

Jacques Chirac

Jean-Marie Le Pen

Lionel Jospin

acques Chirac

Alain Madelin

Corinne Lepage

Jean Saint-Josse

Christine Boutin

Ségolène Royal

François Bayrou

Nicolas Sarkozy

Nicolas Dupont-Aignan

Corinne Lepage

Frédéric Nihous 


\section{Appendix B}

\section{Methodological Issues}

To assess the accuracy of opinion polls we picked the absolute difference between vote intentions for each political groupings and the final vote. We decomposed these errors in systematic bias and hazard bias following Theil's (1966) "decomposition of errors" method.

This method is based on the mean square prediction error. The mean square prediction error is decomposed in order to indicate systemic and random sources of error. The systematic component is further divided into the proportion of the total forecast error due to bias and the proportion of total forecast error attributable to unequal variation.

The forecast error is defined as an equation of the shape UM + US + $\mathrm{UC}$ as follows:

$$
\frac{(\bar{P}-\bar{R})^{2}}{E Q M}+\frac{\left(S_{P}-S_{R}\right)^{2}}{E Q M}+\frac{2(1-r) \cdot\left(S_{P} \cdot S_{R}\right)}{E Q M}=1
$$

$\bar{P}$ and $\bar{R}$ are mean predicted and mean actual changes respectively; $S_{P}$ and $S_{R}$ are the standard deviations of predicted and actual values respectively; and $r$ is the coefficient of correlation between predicted and actual values.

The first expression (UM) of RHS of this equation is the proportion of the total forecast error due to bias. It represents a measure of proportion of error due to over prediction or under prediction of the average value. The second expression of the RHS of this equation (US) is the proportion of total forecast error attributable to unequal variation. In other words, it measures the proportion of error due to overprediction or underprediction of the variance of the values. The third expression of the RHS (UC) of this equation measures the proportion of forecasting error due to random variation.

In order to realize this decomposition, we calculate the coefficient of correlation between predicted and actual values.

$$
r=\frac{\frac{1}{T} \sum(P-\bar{P}) \cdot(R-\bar{R})}{S_{P} \cdot S_{R}}
$$

With $\bar{P}=\frac{\sum P}{T}$ and $\bar{R}=\frac{\sum R}{T}$ 
And $S_{P}^{2}=\frac{\sum(P-\bar{P})^{2}}{T}$ and $S_{R}^{2}=\frac{\sum(R-\bar{R})^{2}}{T}$

With data from TNS-Sofres on French presidential elections from 1981 till 2007, we obtain the following tables.

Calculation of UM for the whole period 1981-2007 (month number before the election)

\begin{tabular}{lcccccc}
\hline \hline & 6 months & 5 months & 4 months & 3 months & 2 months & 1 month \\
\hline exl & 0,675 & 0,524 & 0,683 & 0,578 & 0,479 & 0,356 \\
1 & 0,034 & 0,024 & 0,0004 & 0,027 & 0,003 & 0,001 \\
centre & 0,379 & 0,238 & 0,096 & 0,262 & 0,013 & 0,054 \\
right & 0,178 & 0,282 & 0,052 & 0,199 & 0,064 & 0,100 \\
exr & 0,886 & 0,886 & 0,641 & 0,774 & 0,758 & 0,629 \\
\hline
\end{tabular}

Calculation of US for the whole period 1981-2007 (month number before the election)

\begin{tabular}{lrccccr}
\hline \hline & 6 months & 5 months & 4 months & 3 months & 2 months & 1 month \\
\hline exl & $7,22 \mathrm{E}-34$ & 0,079 & 0,064 & 0,058 & 0,055 & 0,051 \\
left & $4,6 \mathrm{E}-34$ & 0,100 & 0,097 & 0,088 & 0,108 & 0,244 \\
centre & $3,07 \mathrm{E}-34$ & 0,114 & 0,120 & 0,330 & 0,748 & 0,733 \\
right & $4,20 \mathrm{E}-34$ & 0,158 & 0,138 & 0,228 & 0,196 & 0,209 \\
exr & $6,33 \mathrm{E}-34$ & 0,059 & 0,084 & 0,117 & 0,106 & 0,110 \\
\hline
\end{tabular}

Calculation of UC for the whole period 1981-2007 (month number before the election)

\begin{tabular}{lllllll}
\hline \hline & 6 months & 5 months & 4 months & 3 months & 2 months & 1 month \\
\hline exl & 0,324 & 0,396 & 0,2524 & 0,3659 & 0,466 & 0,592 \\
left & 0,964 & 0,875 & 0,903 & 0,884 & 0,888 & 0,755 \\
centre & 0,621 & 0,648 & 0,784 & 0,407 & 0,238 & 0,213 \\
right & 0,821 & 0,560 & 0,810 & 0,571 & 0,740 & 0,690 \\
exr & 0,114 & 0,054 & 0,274 & 0,108 & 0,135 & 0,260 \\
\hline
\end{tabular}

The mean square prediction error has been decomposed in order to indicate systematic source of error. However, other errors exist. In order to avoid them, we remove/add half of the distance between predicted and actual vote. If the score of the political family has been overestimated over the whole period 1981-2007, we remove $\frac{1}{2}(P-R)$. If the score of the political family has been underestimated over the whole period 1981-2007, we add $\frac{1}{2}(P-R)$. The results are shown in the table below. 


\begin{tabular}{rlrccccr}
\hline \hline & & 6 months & 5 months & 4 months & 3 months & 2 months & 1 month \\
\hline 1981 & exl & 30,6 & 28,9 & 27,1 & 29, & 25,5 & 26,1 \\
& left & 21,1 & 19,5 & 20,4 & 24,5 & 25,3 & 25,3 \\
& centre & 29 & 30,5 & 32 & 26,3 & 28,3 & 27,4 \\
& right & 19,3 & 21,1 & 20,5 & 20,2 & 20,9 & 21,2 \\
& exr & 0 & 0 & 0 & 0 & 0 & 0 \\
& sum & 100 & 100 & 100 & 100 & 100 & 100 \\
\hline
\end{tabular}

\begin{tabular}{llcccccc}
\hline \hline & & 6 months & 5 months & 4 months & 3 months & 2 months & 1 month \\
\hline 1988 & exl & 12 & 10,5 & 10,6 & 9,9 & 12,1 & 11,7 \\
& left & 36,8 & 36,0 & 37,8 & 37,4 & 35,7 & 36,1 \\
& centre & 19,1 & 20,0 & 20,7 & 17,9 & 18,7 & 18,5 \\
& right & 18,6 & 20,2 & 19,8 & 21,4 & 20,8 & 21,4 \\
& exr & 13,5 & 13,3 & 11,1 & 13,4 & 12,7 & 12,3 \\
& sum & 100 & 100 & 100 & 100 & 100 & 100 \\
\hline
\end{tabular}

\begin{tabular}{llcccccr}
\hline \hline & & 6 months & 5 months & 4 months & 3 months & 2 months & 1 month \\
\hline 1995 & exl & 15,8 & 16,6 & 18,2 & 18 & 19,5 & 17,9 \\
& left & 23,1 & 22,6 & 17,8 & 21,5 & 21 & 21,1 \\
centre & 14,3 & 12,4 & 16,0 & 14,7 & 21,1 & 21,0 \\
right & 34,3 & 35,6 & 35,0 & 33,5 & 25,6 & 25 \\
& exr & 12,5 & 12,8 & 13 & 12,3 & 12,8 & 15 \\
& sum & 100 & 100 & 100 & 100 & 100 & 100 \\
\hline
\end{tabular}

\begin{tabular}{llcccccr}
\hline \hline & & 6 months & 5 months & 4 months & 3 months & 2 months & 1 month \\
\hline 2002 & exl & 23,2 & 20,8 & 23,5 & 22,5 & 21,5 & 22,9 \\
& left & 21,9 & 23 & 25,5 & 22,8 & 21,5 & 22,8 \\
& centre & 5,8 & 4 & 3,5 & 4,9 & 5,3 & 5,2 \\
& right & 31,6 & 34,0 & 30,1 & 29,0 & 32,1 & 30,3 \\
& exr & 17,5 & 18,2 & 17,4 & 20,8 & 19,6 & 18,8 \\
& sum & 100 & 100 & 100 & 100 & 100 & 100 \\
\hline
\end{tabular}

\begin{tabular}{llcccccr}
\hline \hline & & 6 months & 5 months & 4 months & 3 months & 2 months & 1 month \\
\hline 2007 & exl & 9,8 & 12,7 & 14,6 & 12,6 & 12,7 & 12,5 \\
& left & 30,5 & 32,1 & 31,2 & 29,9 & 25,3 & 25,6 \\
& centre & 6 & 5,9 & 7,2 & 7,7 & 12,6 & 20,3 \\
& right & 39,3 & 31,3 & 32,7 & 32,1 & 32,6 & 27,6 \\
& exr & 14,4 & 18 & 14,3 & 17,7 & 16,8 & 14 \\
& sum & 100 & 100 & 100 & 100 & 100 & 100 \\
\hline
\end{tabular}




\begin{tabular}{llcccccc}
\hline \hline & & 6 months & 5 months & 4 months & 3 months & 2 months & 1 month \\
\hline 1981 & exl & 30.588 & 28.874 & 27.162 & 29.063 & 25.5196085 & 26.1265923 \\
& left & 21.124 & 19.468 & 20.394 & 24.480 & 25.3306319 & 25.3041932 \\
& centre & 28.963 & 30.478 & 31.971 & 26.276 & 28.2354966 & 27.4160576 \\
& right & 19.323 & 21.179 & 20.472 & 20.179 & 20.914263 & 21.1531569 \\
& exr & 0 & 0 & 0 & 0 & 0 & 0 \\
& sum & 100 & 100 & 100 & 100 & 100 & 100 \\
\hline
\end{tabular}

\begin{tabular}{llcccccc}
\hline \hline & & 6 months & 5 months & 4 months & 3 months & 2 months & 1 month \\
\hline 1988 & exl & 11.947 & 10.510 & 10.635 & 9.9145 & 12.085975 & 11.6605576 \\
& left & 36.801 & 36.051 & 37.767 & 37.452 & 35.6696511 & 36.0889313 \\
& centre & 19.129 & 20.011 & 20.732 & 17.877 & 18.685215 & 18.5163196 \\
& right & 18.593 & 20.167 & 19.776 & 21.443 & 20.8219137 & 21.399251 \\
& exr & 13.528 & 13.260 & 11.089 & 13.313 & 12.7372451 & 12.3349404 \\
& sum & 100 & 100 & 100 & 100 & 100 & 100 \\
\hline
\end{tabular}

\begin{tabular}{|c|c|c|c|c|c|c|c|}
\hline & & 6 months & 5 months & 4 months & 3 months & 2 months & 1 month \\
\hline \multirow[t]{6}{*}{1995} & exl & 15.794 & 16.624 & 18.185 & 17.944 & 19.4480218 & 17.9083796 \\
\hline & left & 23.140 & 22.648 & 17.835 & 21.505 & 20.959595 & 21.0925798 \\
\hline & centre & 14.333 & 12.305 & 16.000 & 14.702 & 21.1207285 & 21.0691896 \\
\hline & right & 34.268 & 35.631 & 35.003 & 33.557 & 25.6019079 & 24.9915717 \\
\hline & exr & 12.463 & 12.791 & 12.975 & 12.2905 & 12.8697469 & 14.9382793 \\
\hline & sum & 100 & 100 & 100 & 100 & 100 & 100 \\
\hline
\end{tabular}

\begin{tabular}{clcccccc}
\hline \hline & & 6 months & 5 months & 4 months & 3 months & 2 months & 1 month \\
\hline 2002 & exl & 23.120 & 20.801 & 23.550 & 22.496 & 21.4734983 & 22.8954512 \\
& left & 21.951 & 22.995 & 25.462 & 22.801 & 21.4823696 & 22.7857217 \\
& centre & 5.820 & 3.927 & 3.526 & 4.923 & 5.27048992 & 5.19994795 \\
& right & 31.568 & 34.058 & 30.062 & 29.003 & 32.121114 & 30.3165859 \\
& exr & 17.539 & 18.218 & 17.399 & 20.775 & 19.6525282 & 18.8022933 \\
& sum & 100 & 100 & 100 & 100 & 100 & 100 \\
\hline
\end{tabular}

\begin{tabular}{clcccccc}
\hline \hline \multicolumn{1}{c}{ 6 months } & 5 months & 4 months & 3 months & 2 months & 1 month \\
\hline 2007 & exl & 9.764 & 12.694 & 14.584 & 12.605 & 12.6965129 & 12.5428278 \\
& left & 30.506 & 32.165 & 31.183 & 29.931 & 25.3202991 & 25.6353228 \\
& centre & 5.974 & 5.907 & 7.199 & 7.652 & 12.5965588 & 20.2462348 \\
& right & 39.3197 & 31.267 & 32.681 & 32.161 & 32.5724239 & 27.5786927 \\
& exr & 14.435 & 17.966 & 14.3523 & 17.651 & 16.8142054 & 13.9969219 \\
& sum & 100 & 100 & 100 & 100 & 100 & 100 \\
\hline
\end{tabular}

For each election between 1981-2007 (including 2007), we calculated this corrected distribution of votes one month before each presidential election, picking the two highest modes, which will be the two candidates running for the second round, and calculated the distance of each mode to the overall median voter. Then we predicted the winner as the one who is closer to the overall median voter. 